\title{
SYNTHESIS AND CHARACTERIZATION OF SCHIFF BASE AND ITS TRANSITION METAL COMPLEXES DERIVED FROM 3-ETHOXYSALICYLALDEHYDE AND P-TOLUIDINE
}

\author{
K. Sirumalar ${ }^{1}$, M. Paul Johnpeter ${ }^{2}$, R. Manikandan ${ }^{2}$, A. P. Mary Sri Archana ${ }^{1}$ \\ and A. Paulraj ${ }^{1, \bigotimes}$ \\ ${ }^{1}$ Department of Chemistry, St. Joseph's College (Autonomous), Tiruchirappalli-620 002, \\ Tamil Nadu, India. \\ ${ }^{2}$ Department of Chemistry, Loyola College of Arts and Science, Mettala, Namakkal-636 202, \\ Tamil Nadu, India. \\ ${ }^{\circledR}$ Corresponding Author: paulrajsjc@gmail.com
}

\begin{abstract}
By Micro elemental analysis, FTIR, Ultra Violet-Visible, Thermal analysis, ${ }^{1} \mathrm{H} \&{ }^{13} \mathrm{C}$ NMR, ESR and Antimicrobial studies a total of four new metal complex derivatives of 2-((p-tolyliminomethyl)-6-ethoxyphenol (EST-L) with the metal ions $\mathrm{Mn}(\mathrm{II}), \mathrm{Co}(\mathrm{II}), \mathrm{Cu}(\mathrm{II})$ and $\mathrm{Zn}(\mathrm{II})$ have been synthesized and characterized quantitatively and qualitatively. It is shown through the spectral study that the geometrical, structural and octahedral geometries for $\mathrm{Mn}(\mathrm{II}), \mathrm{Co}(\mathrm{II}), \mathrm{Cu}(\mathrm{II})$ complexes and square planar for $\mathrm{Zn}(\mathrm{II})$ complex respectively. The presence of unpaired electrons in $\mathrm{dx}^{2}-\mathrm{y}^{2}$ orbital and distortion in octahedral geometry of $\mathrm{Cu}$ (II) complex is confirmed by the ESR spectra. Under the biological evaluation, all the synthesized compounds were closed.

Keywords: Schiff Base, Metal Complexes, Spectral Characterization, Biological Studies.
\end{abstract}

RASĀYAN J. Chem., Vol. 14, No.2, 2021

\section{INTRODUCTION}

In many biological aspects, the Schiff bases area very important class of organic compounds with a wide range of applications. ${ }^{1-2}$ The metal complexes of Schiff bases posse's extraordinary properties as catalysts in numerous biological systems, polymer dyes, antimicrobial activities, antifungal activities, antiviral and antibacterial activities, insecticides, antitumor, plant growth regulator, enzymatic and pharmaceutical fields ${ }^{3-7}$. Because of its biological relevance, several model systems including those with bidentate, tridentate, tetradentate, multidentate Schiff base ligands and their coordination complexes attract much attention. This study presents the synthesis, characterization, and biological activities of 2-((p-tolylimino)6-ethoxyphenol (EST-L) and its transition metal complexes.

\section{EXPERIMENTAL}

Without using further purification, the chemical and solvents used are of inorganic and bio-applications grade. At room temperature, all the experiments are carried out, unless otherwise stated. All the metal (II) salts are used as chlorides.

\section{Physical Measurements}

On CHNS Perkin Elmer 2400 elemental analyzer, microanalytical data $(\mathrm{C}, \mathrm{H}$ and $\mathrm{N})$ is collected. From the following studies, the spectroscopic data is obtained in the range of 200-800 nm, spectra Perkin Elmer UV-Visible spectrophotometer model lambda 25, using NMR spectrometer Bruker Advance (II) (400 $\mathrm{MH}_{\mathrm{Z}}, \mathrm{d}_{6}-\mathrm{DMSO}$ - solvent). ${ }^{1} \mathrm{H}$ and ${ }^{13} \mathrm{C}$ NMR spectra of 2-((p-tolylimino)-6-ethoxyphenol (EST-L) and their complexes are recorded. On STH 6000 Perkin Elmer instrument the Thermo Gravimetric Analysis is done under an inert $\mathrm{N}_{2}$ gas atmosphere. In dimethyl formamide, the Electron Proton Resonance spectra 
RASĀYAN J. Chem.

Vol. 14 | No. 2 |1316-1321| April - June | 2021

are recorded at room temperature (298K) and liquid nitrogen temperature (77K) using Bruker EPR spectrometer EMX 10/(2) X-bond ER 4119 HS cylindrical resonator.

\section{Synthesis of 2-((p-tolylimino)methyl)-6-ethoxyphenol (EST-L)}

The 2-((p-tolylimino)methy)-6-ethoxyphenol (EST-L) is synthesized from the solution of 3-ethoxy salicylaldehyde $(0.05 \mathrm{~mol})$ dissolved in absolute ethanol $(20 \mathrm{ml})$ and P-toluidine $(0.05 \mathrm{~mol})$ is added in an equimolar (1:1) ratio. At room temperature the reaction mixture is then stirred for 1-2 hrs. The solid product is separated, filtered and washed from ethyl alcohol. The typical yield $74 \%$; FTIR $\left(\mathrm{KBr}, \mathrm{cm}^{-1}\right)$ : $3435\left(\mathrm{H}_{2} \mathrm{O}\right), 3048(-\mathrm{OH}), 1660(-\mathrm{HC}=\mathrm{N}), 1251(\mathrm{C}-\mathrm{O}) ;{ }^{13} \mathrm{C}$ NMR $\left(100 \mathrm{MHz}, \mathrm{d}_{6}-\mathrm{DMSO}\right) \delta=77.34-$ 76.70 $\left(\mathrm{OC}_{2} \mathrm{H}_{5}\right)$, 114.6-147.7(Ar-Carbon), 151.7(HC=N), 161.6(Ph-C-O); ${ }^{1} \mathrm{H}$ NMR (400 MHZ, $\mathrm{d}_{6}-\mathrm{DMSO}$, ppm) $\delta=13.89(\mathrm{~s}, 1 \mathrm{H}, \mathrm{Ar}-\mathrm{C}-\mathrm{O}), 8.62(\mathrm{~s}, 1 \mathrm{H}, \mathrm{HC}=\mathrm{N}), 6.84-7.20(\mathrm{~m}, 8 \mathrm{H}, \mathrm{Ar}-\mathrm{H}) 4.17-3.93\left(\mathrm{~m}, 5 \mathrm{H},-\mathrm{OC}_{2} \mathrm{H}_{5}\right)$; Analytical: C-75.27, H-6.71, N-5.49; Found: C-74.93, H-6.96, N-5.14.

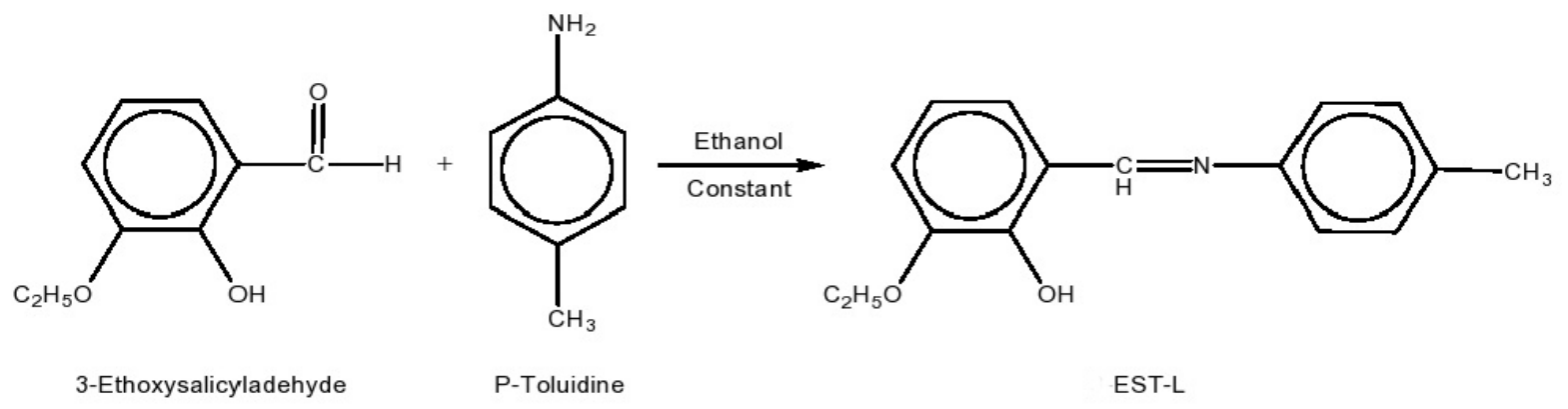

Scheme-1: Formation of 2-((p-tolylimino)methyl)-6-ethoxyphenol (EST-L)

\section{Synthesis of Mn(II), Co(II), Cu(II) and $\mathrm{Zn}(\mathrm{II})$ Complexes}

To a hot ethanolic solution $(20 \mathrm{ml})$ of respective metal chlorides $(0.05 \mathrm{~mol})$ is added with the hot solution corresponding 2-((p-tolylimino)-6-ethoxyphenol (EST-L) $(0.05 \mathrm{~mol})$ in ethanol $(20 \mathrm{ml})$ and the reaction mixture is refluxed for about 5-6 hrs on the mantle with a water condenser and then cooled with an ice bath. The obtained colored solid precipitates are collected by filtration washed with a sufficient quantity of ethanol and are dried in a hot air oven (Scheme-2).

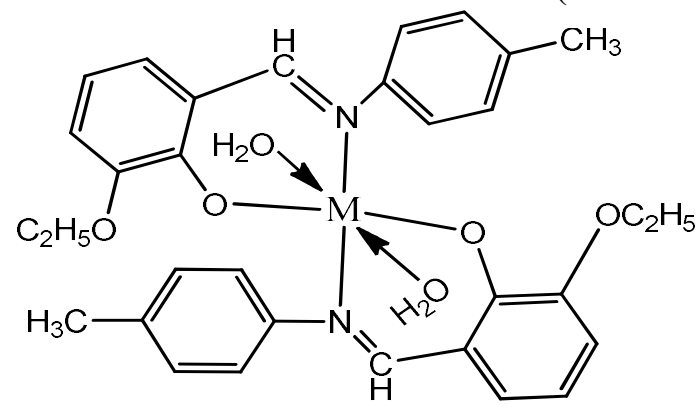

$\mathrm{M}=\mathrm{Mn}(\mathrm{II}), \mathrm{Co}(\mathrm{II}), \mathrm{Cu}(\mathrm{II})$

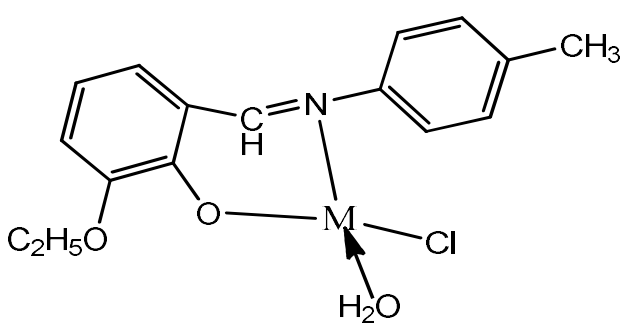

$M=Z n(I I)$

\section{$\left[\mathrm{Mn}(\mathrm{EST})_{2}\left(\mathrm{H}_{2} \mathrm{O}\right)_{2}\right]$}

Scheme-2: Structures of Metal Complexes

The typical yield 67\%; Solid; FTIR $\left(\mathrm{KBr}, \mathrm{cm}^{-1}\right)$ : 3394( $\left.\mathrm{H}_{2} \mathrm{O}\right), 1634(\mathrm{CH}=\mathrm{N}), 1238(\mathrm{C}-\mathrm{O}), 532(\mathrm{M}-\mathrm{O})$, 490(M-N); Analytical: C-64.10, H-6.05, N-4.67; Found: C-65.32, H-6.01, N-4.21.

\section{$\left[\mathrm{Co}(\mathrm{EST})_{2}\left(\mathrm{H}_{2} \mathrm{O}\right)_{2}\right]$}

The typical yield 68\%; Solid; FTIR $\left(\mathrm{KBr}, \mathrm{cm}^{-1}\right)$ : 3392( $\left.\mathrm{H}_{2} \mathrm{O}\right), 1636(\mathrm{HC}=\mathrm{N}), 1242(\mathrm{C}-\mathrm{O}), 575(\mathrm{M}-\mathrm{O})$, 492(M-N); Analytical: C-63.38, H-6.01, N-4.64; Found: C-65.61, H-6.23, N-4.12.

\section{$\left[\mathrm{Cu}(\mathrm{EST})_{2}\left(\mathrm{H}_{2} \mathrm{O}\right)_{2}\right]$}

The typical yield 67\%; Solid; FTIR $\left(\mathrm{KBr}, \mathrm{cm}^{-1}\right)$ : 3425( $\left.\mathrm{H}_{2} \mathrm{O}\right), 1637(\mathrm{HC}=\mathrm{N}), 1244(\mathrm{C}-\mathrm{O}), 575(\mathrm{M}-\mathrm{O})$, 492(M-N); Analytical: C-63.20, H-5.97, N-4.61; Found: C-62.19, H-5.82, N-4.82. 
RASĀYAN J. Chem.

Vol. 14 | No. 2 |1316-1321| April - June | 2021

\section{[Zn(EST)(Cl)( $\left.\left.\mathrm{H}_{2} \mathrm{O}\right)\right]$}

The typical yield 67\%; Solid; FTIR $\left(\mathrm{KBr}, \mathrm{cm}^{-1}\right)$ : 3367( $\left.\mathrm{H}_{2} \mathrm{O}\right), 1639(-\mathrm{HC}=\mathrm{N}), 1240(\mathrm{C}-\mathrm{O}), 577(\mathrm{M}-\mathrm{O})$, 491(M-N); ${ }^{13} \mathrm{C} \quad \mathrm{NMR} \quad\left(100 \mathrm{MHz}, \quad \mathrm{d}_{6}-\mathrm{DMSO}\right): \quad \delta=77.36-56.21\left(-\mathrm{OC}_{2} \mathrm{H}_{5}\right), 114.6-137.0($ Ar-Carbons), 151.7 $(\mathrm{HC}=\mathrm{N}), 161.6(\mathrm{Ph}-\mathrm{C}-\mathrm{O}) ;{ }^{1} \mathrm{H} \mathrm{NMR}\left(400 \mathrm{MHZ}, \mathrm{d}_{6}-\mathrm{DMSO}\right) ; \delta=8.78(\mathrm{~s}, 1 \mathrm{H}, \mathrm{HC}=\mathrm{N}), 6.85-7.26(\mathrm{~m}, 8 \mathrm{H}$, Ar-H), 3.93-2.00(m, 5H, $-\mathrm{OC}_{2} \mathrm{H}_{5}$ ); Analytical: C-51.50, H-4.86, N-3.75; Found: C-52.41, H-4.76, N-4.01.

\section{RESULTS AND DISCUSSION}

Elemental analysis $(\mathrm{C}, \mathrm{H}, \mathrm{N}), \mathrm{UV}-$ Visible, FTIR, ${ }^{1} \mathrm{H}$ and ${ }^{13} \mathrm{C}$ NMR, ESR, TGA and Antimicrobial studies characterize the synthesized 2-((p-tolylimino)-6-ethoxyphenol (EST-L)and metal complexes.

\section{Infrared Spectra}

Due to the azomethine, the IR spectra of the ligand exhibit a strong band at $1660 \mathrm{~cm}^{1}$. A shift of this band towards lower frequency by $20-30 \mathrm{~cm}^{-1}$ in all the complexes suggests that the azomethine nitrogen coordination to the metal centers. ${ }^{8}$ The ligand 2-((p-tolylimino)-6-ethoxyphenol (EST-L) IR spectrum shows a band at $3048 \mathrm{~cm}^{-1}$ which corresponds to the phenolic $v(\mathrm{OH})$ group. $\mathrm{OH}$ phenolic group bands disappear in the complexes which indicate the coordination of phenolic oxygen to the metal atom. Further, a strong sharp band characteristic of $v(\mathrm{C}-\mathrm{O})$ in the region $1251 \mathrm{~cm}^{-1}$ observed in the free Schiff base ligand was shifted to lower frequencies $1244-1238 \mathrm{~cm}^{-1}$ in the metal complexes. ${ }^{9}$ To $v(\mathrm{M}-\mathrm{N})$ the presence of a new band around $495-490 \mathrm{~cm}^{-1}$ is assignable. The emergence of the new band in the region of $530-580 \mathrm{~cm}^{-1}$ in all the complexes is due to $v(\mathrm{M}-\mathrm{O}) .{ }^{10}$

\section{UV-Visible Spectra}

The banding range 412-665 nm is assigned in the spectra of metal complexes to LMCT and d-d transition respectively. In respect of ligand2-((p-tolylimino)-6-ethoxyphenol (EST-L), the absence of these charge transfer bands confirms the coordination of metal complexes ${ }^{11}$. In the UV part of the spectrum as well as in the visible part, the colored complexes exhibit a series of the overlapping absorption band. A distorted octahedral geometry is shown by the metal complexes of $\mathrm{Mn}(\mathrm{II}), \mathrm{Co}(\mathrm{II}), \mathrm{Cu}$ (II) and the $\mathrm{Zn}$ (II) complex shows distorted square planar as a stable geometry.

\section{${ }^{1} \mathrm{H}$ and ${ }^{13} \mathrm{C}$ NMR Spectra}

In DMSO- ${ }_{6}{ }_{6} \mathrm{H}$ NMR spectra of Schiff base ligand andZn(II) complex were noted. In the free ligand 2-((p-tolylimino)-6-ethoxyphenol (EST-L), the signal due to the azomethine proton at $8.62 \mathrm{ppm}(\mathrm{s}, 1 \mathrm{H}$, $\mathrm{CH}=\mathrm{N})^{9}$ and the multiplet which extends from $6.84-7.20 \mathrm{ppm}$ corresponds to the protons of the aromatic ring $(\mathrm{m}, \mathrm{Ar}-\mathrm{H})$. the peak at $13.89 \mathrm{ppm}$ confirms the presence of $\mathrm{OH}$ proton in ligand ${ }^{12}$. In the spectrum of $\mathrm{Zn}$ (II) complex, the $\mathrm{OH}$ proton is disappeared by complexation with a metal ion. The signal appeared at $8.78 \mathrm{ppm}$ and multiplets in the region of 6.85-7.26 in ${ }^{1} \mathrm{HNMR}$ spectrum of the $\mathrm{Zn}$ (II) complex are due to azomethine proton and aromatic protons respectively. The signals due to proton have been shifted towards downfield strengths confirming the complexation of metal (II) ion with the ligand. In addition, the signals of ligand2-((p-tolylimino)-6-ethoxyphenol (EST-L) and Zn(II) complex appeared in the region 3.93-4.17 and 2.00-3.93 ppm has been assigned to the $-\mathrm{OC}_{2} \mathrm{H}_{5}$ proton. In ${ }^{13} \mathrm{C}$ NMR spectra of the ligand2((p-tolylimino)-6-ethoxyphenol (EST-L), the phenolic $\mathrm{C}-\mathrm{O}, \mathrm{HC}=\mathrm{N}$ and aromatic carbon atoms appear in the region of $165.13,159.20,132.49-121.05 \mathrm{ppm}$, which is in agreement with various values reported in the literature. In $\mathrm{Zn}(\mathrm{II})$ metal complex, the signal appeared at $\delta 151.50 \mathrm{ppm}(\mathrm{C}=\mathrm{N}, 1 \mathrm{C})$ was assigned to azomethine carbon atom and the signal at $\delta 161.63 \mathrm{ppm}(\mathrm{ph}-\mathrm{C}-\mathrm{O}, 1 \mathrm{C})$ was assigned to phenolic carbon. The phenyl rings of complexes showed signals between $\delta 114.07-147.20 \mathrm{ppm}(\mathrm{Ar}-\mathrm{C})$. The $-\mathrm{OC}_{2} \mathrm{H}_{5}$ signals appeared at 77.34-76.70 and 77.36-56.21 ppm in ligand 2-((p-tolylimino)-6-ethoxyphenol (EST-L)and $\mathrm{Zn}$ (II) complex.

\section{Thermal Analysis of $\mathrm{Zn}(\mathrm{II})$ Complex}

Under nitrogen gas at a heating range $25-1000{ }^{\circ} \mathrm{C}$ and heating rate $\left(10{ }^{\circ} \mathrm{C} / \mathrm{min}\right)$ (Fig.-1) Thermo gravimetric analysisof $\mathrm{Zn}(\mathrm{II})$ complex are studied, to prove the suggested structures and studies the thermal stability of the complexes, the thermal analysis is performed. TGA curves of the $\mathrm{Zn}$ (II) complex 
were represented and the thermal decomposition takes place in three stages. Between the temperatures range of $120-150^{\circ} \mathrm{C}$ water $\left(\mathrm{H}_{2} \mathrm{O}\right)$ molecules decomposed and the observed mass loss was recorded as $15.87 \%$. The second stage corresponds to the decomposition of $\mathrm{Cl}$ atom at $190-210^{\circ} \mathrm{C}$. The major step of decomposition takes place ligand was decomposed in the temperature range $270-340^{\circ} \mathrm{C}$ and the observed mass loss was recorded as $49.14 \%$.

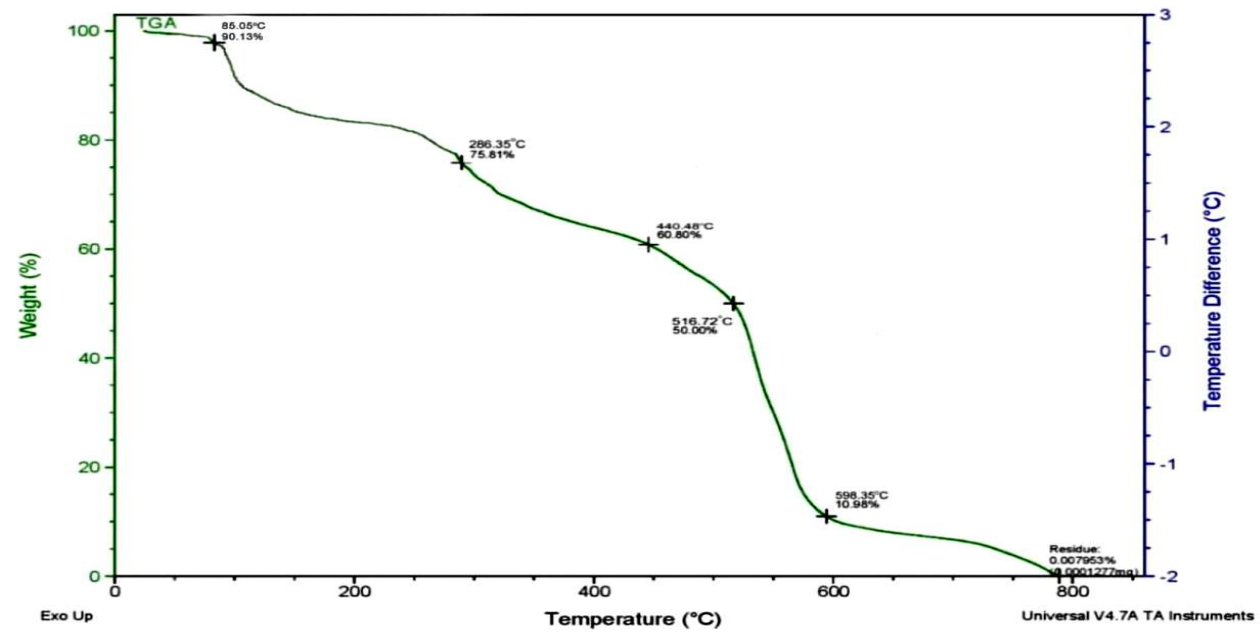

\section{ESR Spectra}

Fig.-1: TGA Spectrum of Zn(II) Complex

At room temperature (Fig.-2), the Electron Spin Resonance Spectra of the $\mathrm{Cu}$ (II) complex is recorded. The unpaired electron is localized in that $\mathrm{dx}^{2}-\mathrm{y}^{2}$ orbital which is further supported by the values of exchange interaction, in term of $\mathrm{G}$ value estimated from the expression is suggested that,

$$
\mathrm{G}=(\mathrm{gII}-2.0023 / \mathrm{g} \vdash-2.0023)
$$

If $\mathrm{G}>\mathrm{L}$; slightly misaligned (or) the local axis is aligned parallel. If $\mathrm{G}>\mathrm{L}$, a significant exchange coupling is presented and misaligned is appreciable. The local tetragonal axes are aligned parallel (or) slightly aligned and the unpaired electron is present in the $\mathrm{dx}^{2}-\mathrm{y}^{2}$ orbital is suggested that the observed value for the exchange interaction parameters for the $\mathrm{Cu}(\mathrm{II})$ complex $\left(\mathrm{Cu}(\mathrm{EST})_{2}\left(\mathrm{H}_{2} \mathrm{O}\right)_{2}\right)$.

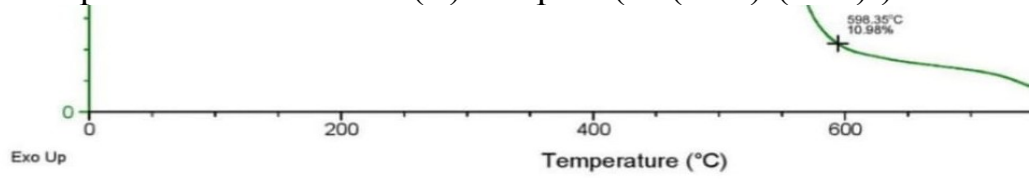

Fig.15. TGA Spectrum of Zn(II) Complex

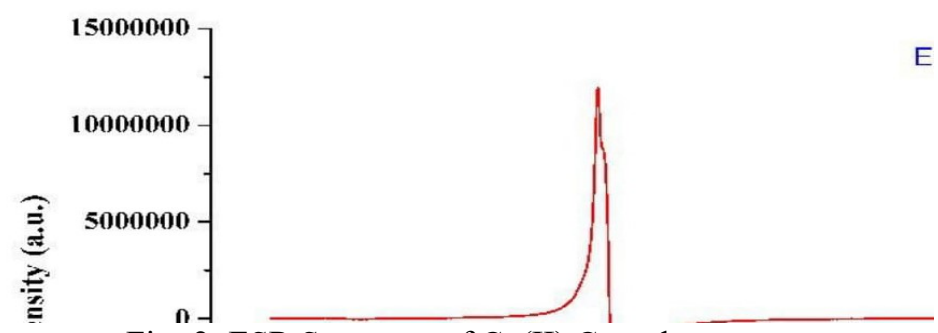

Fig.-2: ESR Spectrum of $\mathrm{Cu}(\mathrm{II})$ Complex

\section{Antimicrobial Activity of 2-((p-tolylimino)-6-ethoxyphenol (EST-L) and its Metal Complexes}

As a result, in this study, the metal complexes have high inhibition efficiency than the EST-L against the bacterial species. And they were also taken to determine the antifungal activity of the metal complexes.

\section{Antibacterial Activities}

The antibacterial activity of the complexes and 2-((p-tolylimino)-6-ethoxyphenol (EST-L) was determined by disc diffusion method on E.coli and S.aureus and compared with the metal 
complexesStreptomycin is used as standard.The ligand 2-((p-tolylimino)-6-ethoxyphenol (EST-L) and the metal complexes exhibited variable antibacterial activities against both E.coli and S.aureus are summarized in Table-1. The result shows that the metal complexes have good activity comparedto that of the free ligand 2-((p-tolylimino)-6-ethoxyphenol (EST-L). This fact confirms the tweedy chelation theory. Thus, the order of activity of the metal complexes and 2-((p-tolylimino)-6-ethoxyphenol (EST-L) against gram-negative bacterium E.coli is $\mathrm{Cu}(\mathrm{EST})_{2}\left(\mathrm{H}_{2} \mathrm{O}\right)_{2}>\mathrm{Mn}(\mathrm{EST})_{2}\left(\mathrm{H}_{2} \mathrm{O}\right)_{2}>\mathrm{Zn}(\mathrm{EST})(\mathrm{Cl})\left(\mathrm{H}_{2} \mathrm{O}\right)>\mathrm{Co}(\mathrm{EST})_{2}\left(\mathrm{H}_{2} \mathrm{O}\right)_{2}>$ EST-L. It is clear from the above order of activity that $\mathrm{Cu}(\mathrm{II}), \mathrm{Zn}$ (II) and $\mathrm{Mn}$ (II) complexes are highly active against E.coli and Co(II) complex is moderately active. The order of activity of the metal complexes and2-((p-tolylimino)-6ethoxyphenol (EST-L) against gram-positive bacterium S.aureus is $\mathrm{Cu}(\mathrm{EST})_{2}\left(\mathrm{H}_{2} \mathrm{O}\right)_{2} \approx \mathrm{Co}(\mathrm{EST})_{2}\left(\mathrm{H}_{2} \mathrm{O}\right)_{2}>\mathrm{Mn}(\mathrm{EST})_{2}\left(\mathrm{H}_{2} \mathrm{O}\right)_{2}>\mathrm{Zn}(\mathrm{EST})(\mathrm{Cl})\left(\mathrm{H}_{2} \mathrm{O}\right)>$ EST-L. Similarly, the order of activity shows that $\mathrm{Cu}$ (II) and $\mathrm{Co}$ (II) complexes are highly active against $S$.aureusand $\mathrm{Mn}$ (II) and $\mathrm{Zn}$ (II) complexes are moderately active.

\section{Antifungal Activities}

Based on the results obtained the order ofresistivity of the metal complexes against the fungal species A.niger is given as $\mathrm{Cu}(\mathrm{EST})_{2}\left(\mathrm{H}_{2} \mathrm{O}\right)_{2} \approx \mathrm{Co}(\mathrm{EST})_{2}\left(\mathrm{H}_{2} \mathrm{O}\right)_{2}>\mathrm{Mn}(\mathrm{EST})_{2}\left(\mathrm{H}_{2} \mathrm{O}\right)_{2}>\mathrm{Zn}(\mathrm{EST})(\mathrm{Cl})\left(\mathrm{H}_{2} \mathrm{O}\right)>\mathrm{EST}-\mathrm{L}$. According to the values, it explains that $\mathrm{Cu}$ (II), $\mathrm{Co}(\mathrm{II})$ and $\mathrm{Mn}$ (II) complexes are highly resistive against A.nigerfungal species. $\mathrm{Zn}$ (II) complex is moderately resistive against A.niger.

Table-1: Antimicrobial Activities of 2-((p-tolylimino)-6-ethoxyphenol (EST-L)and its Metal Complexes

\begin{tabular}{c|c|c|c}
\hline \multirow{2}{*}{ Compound } & \multicolumn{3}{|c}{ Zone of Inhibition $(\mathrm{mm})$} \\
\cline { 2 - 4 } & E.coli $(-)$ & S.aureus. $(+)$ & A.niger \\
\hline EST-L & 5 & 5 & 5 \\
\hline$\left[\mathrm{Mn}(\mathrm{EST})_{2}\left(\mathrm{H}_{2} \mathrm{O}\right)_{2}\right]$ & 8 & 7 & 7 \\
\hline$\left[\mathrm{Co}(\mathrm{EST})_{2}\left(\mathrm{H}_{2} \mathrm{O}\right)_{2}\right]$ & 6 & 8 & 8 \\
\hline$\left[\mathrm{Cu}(\mathrm{EST})_{2}\left(\mathrm{H}_{2} \mathrm{O}\right)_{2}\right]$ & 11 & 12 & 8 \\
\hline$\left[\mathrm{Zn}(\mathrm{EST})(\mathrm{Cl})\left(\mathrm{H}_{2} \mathrm{O}\right)\right]$ & 7 & 6 & 6 \\
\hline Streptomycin - Std. & 8 & 8 & 11 \\
\hline DMF - solvent control & 2 & 1 & 1 \\
\hline
\end{tabular}

CONCLUSION

The analytical data and spectral data discussed above suggest that the metal complexes $\mathrm{Mn}$ (II), Co(II) and $\mathrm{Cu}$ (II) have theproposed geometry is octahedral and $\mathrm{Zn}$ (II) has the proposed geometry is a square planner.The antimicrobial study shows that, metal complexes aremore active than ligands. The antimicrobial activity of $\mathrm{Cu}$ (II) complex is more biologically active than other complexes.

\section{ACKNOWLEDGEMENT}

The author K. SIRUMALARacknowledges the Principal and Management of St. Joseph's College, Tiruchirappalli and is grateful to Dr. A. PAULRAJ for their support and providing necessary facilities. The author is also thankful to ACIC of SJC, IIT Madras, CECRI - karaikudi for the provision of instrumentation.

\section{REFERENCES}

1. N.E.A. El-Gamel, RSC Advances, 2, 5870(2012), DOI:10.1039/C2RA20733H

2. M.J. Gemi, C. Biles, B.J. Keiser, S.M. Poppe, S.M. Swaney, W.G. Tarapley, D.L. Romeso, Y. Yage, Journal of Medicinal Chemistry, 43, 1034(2000), DOI:10.1021/jm990383f

3. Omima M.I. Adly, Hoda F. El-Shafiy, M. Shebl, Journal of Molecular Structure, 1196, 805(2019), DOI:10.1016/j.molstruc.2019.07.010

4. N. Raman, S. Sobha, L. Mitu, Journal of Saudi Chemical Society, 17, 151(2013), DOI:10.1016/j.jscs.2011.03.003

5. C.T. Supuran, M. Barboiu, C. Luca, E. Pop, M.E. Brewster, A. Dinculescu, European Journal of Medicinal Chemistry, 31, 597(1996), DOI:10.1016/0223-5234(96)89555-9 
RASĀYAN J. Chem.

Vol. 14 | No. 2 |1316-1321| April - June | 2021

6. L.H. Abdel-Rahman, A.M. Abu-Dief, R.M. El-Khatib, S.M. Abdel-Fatah, Bioorganic Chemistry, 69, 140(2016), DOI:10.1016/j.bioorg.2016.10.009

7. L.H. Abdel-Rahman, A.M. Abu-Dief, M.O. Aboelez, A.A.H. Abdel-Mawgoud, Journal of Photochemistry and Photobiology B: Biology, 170, 271(2017), DOI:10.1016/j.jphotobiol.2017.04.003

8. R. Kalarani, M. Sankarganesh, G.G. Vinoth Kumar, M. Kalanithi, Journal of Molecular Structure, 1206, 127725 (2020), DOI:10.1016/j.molstruc.2020.127725

9. H. Bahron, S.S. Khaidir, A.M. Tajuddin, K. Ramasamy, B.M. Yamin, Polyhedron, 161, 84(2019), DOI:10.1016/j.poly.2018.12.055

10. R.S. Bhaskar, C.A. Ladole, N.G. Salunkhe, J.M. Barabde, A.S. Aswar, Arabian Journal of Chemistry (2020), DOI:10.1016/j.arabjc.2020.06.012

11. Md. Kudrat-E-Zahan, M.S. Islam, Md. Abul Bashar, Russian Journal of Chemistry, (85)3, 667(2015), DOI:10.1134/S1070363215030238

12. F. Forouzandeh, H. Keypour, M.H. Zebarjadian, M. Mahmoudabadi, L. Hosseinzadeh, R. Karamian, M. AhmadiKhoei, R William Gable, Polyhedron, 160, 238(2019), DOI:10.1016/j.poly.2018.12.052

[RJC-6283/2020] 